\title{
Latent Effects of Haemolytic Agents
}

\author{
BY F. BERGMANN AND MIRIAM KIDRON \\ Department of Pharmacology, The Hebrew University \\ Hadassah Medical School, Jerusalem, Israel
}

(Received 16 December 1965)

\begin{abstract}
SUMMARY
Although staphylococcal $\beta$-haemolysin does not lyse rabbit erythrocytes, it is absorbed by these cells and produces a prelytic change which can be recognized by facilitation of other haemolytic reactions. Combination of two haemolytic processes serves in general to detect latent effects of lytic agents or to accelerate their quantitative evaluation. $\beta$-Haemolysin apparently causes the same primary change in sheep and rabbit erythrocytes, namely enzymic splitting of sphingomyelin and related compounds, but only the sheep cells, when subjected to cooling, are able to undergo a second reaction, responsible for the release of haemoglobin.
\end{abstract}

\section{INTRODUCTION}

The effect of many haemolytic agents appears with considerable delay, indicating that the lytic process consists of at least two separate phases (Menk, 1932): (a) Attachment of the active compound to the red cell; and (b) the actual disruption of the cell wall, leading to the release of haemoglobin. The combination of the red cell with a haemolysin is often irreversible, i.e. brief exposure is sufficient to let the reaction continue even after the erythrocytes have been separated by centrifugation. However, in this case the extent of haemolysis is usually smaller than when the cells are left in continuous contact with the lytic agent (Cooper, Madoff \& Weinstein, 1964; Reich, Bergmann \& Kidron, 1965).

The interval between the attachment of a lytic substance and the actual escape of haemoglobin is apparently required to let the chemical reaction progress through the various layers of the membrane structure. Frequently, early alterations of membrane permeability can be recognized, e.g. by prelytic potassium release, before any morphological changes (swelling and disruption of cells) become visible (Davson \& Danielli, 1938; Jacob \& Jandl, 1962; Madoff, Cooper \& Weinstein, 1964). In the present study, we shall show that such prelytic effects can also be demonstrated by facilitation of unspecific or specific lytic processes. In addition, the facilitation method uncovers interactions even in cases where the erythrocytes of a given species appear to be resistant to a haemolytic agent.

\section{METHODS}

Staphylococcal $\beta$-haemolysin or $\beta$-toxin. This material was purchased from Burroughs Wellcome, London. At a concentration of 0.005 international units (i.u.) per ml., it produced $\mathbf{5 0} \%$ haemolysis of sheep erythrocytes, when the hot-cold 
method (Jackson \& Mayman, 1958) was used. This concentration is designated as $H_{50}$. The lack of haemolytic action against rabbit erythrocytes, even when a concentration 100 times the $H_{50}$ value for sheep cells was used, served to establish the absence of $\alpha$-haemolysin in the commercial preparation.

Prymnesin. The purified toxin of Prymnesium parvum Carter was prepared according to the method described previously (Bergmann, Parnas \& Reich, 1964). The material used in the present experiments had an $H_{50}$ value of $3 \mu \mathrm{g} . / \mathrm{ml}$. when haemolysis was measured after $45 \mathrm{~min}$. and of $1.1 \mu \mathrm{g} . / \mathrm{ml}$. when the reaction time was $150 \mathrm{~min}$. This toxin thus differed from the preparation used in our earlier experiments, where the maximal lytic effect was attained after about $40 \mathrm{~min}$. (Reich, Bergmann \& Kidron, 1965). The change of behaviour (see Table 2) is probably due to a modification in the culture conditions of the phytoflagellate, which will be described elsewhere.

Ehrlich ascites carcinoma cells. These cells were collected from the peritoneal cavity of mice 7-11 days after inoculation. The cells were centrifuged at $4500 \mathrm{rev}$./ min. during $5 \mathrm{~min}$., the temperature being kept below $+10^{\circ}$, and were washed twice with saline. One ml. of the sediment contained about $5 \times 10^{8}$ cells. The ascites cells were prepared for microscopic examination by fixation in methanol and staining with haematoxylin-eosin.

Erythrocytes. Blood was collected into glass tubes and shaken with glass beads. The erythrocytes were separated by centrifugation and washed with saline until the supernatant was colourless. Finally, they were diluted with saline $(\mathrm{pH} 7)$ to give a $7 \%$ suspension.

Haemolysis. (a) Test-tube method. One ml. each of the $7 \%$ suspension of erythrocytes and of the haemolytic agent, dissolved in saline, were incubated at $37^{\circ}$ with 5 ml. of PBS (phosphate-buffered saline; Jackson \& Little, 1957). The supernatant, obtained after centrifugation, was diluted with $2 \cdot 5$ volumes of bicarbonate buffer and the extinction measured at $540 \mathrm{~m} \mu$. Complete haemolysis of a standard sample was effected by treatment with distilled water.

The bicarbonate buffer contained 3 vol. of $0.1 \% \mathrm{Na}_{2} \mathrm{CO}_{3}$ and 1 vol. of $0 \cdot 1 \% \mathrm{NaHCO}_{3}$.

(b) Fragiligraph (Danon, 1963). This instrument, supplied by Elron Inc., Haifa, Israel, contains a semi-permeable cell, into which is placed the buffered suspension of erythrocytes. The outer compartment is filled with distilled water of $37^{\circ}$. The progress of the reaction is recorded automatically (see Fig. 2).

\section{RESULTS \\ Absorption of $\beta$-haemolysin by 'resistant' cells}

When erythrocytes are exposed to an agent like prymnesin, the ichthyotoxin from Prymnesium parvum Carter, the haemolytic action starts with a delay of about $15 \mathrm{~min}$. (Reich et al. 1965). However, even short contact with the toxin is sufficient for binding. Thus, a solution containing $14 \mu \mathrm{g} . / \mathrm{ml}$. prymnesin was incubated at $+5^{\circ}$ with 4 batches of rabbit erythrocytes, each time for 2 min., i.e. a period too short to produce visible haemolysis. After the fourth batch of cells had been removed by centrifugation, the activity of the supernatant was tested against fresh rabbit cells at $37^{\circ}$. Incubation for $45 \mathrm{~min}$. produced only $15 \%$ haemolysis 
indicating that the remaining concentration of prymnesin was less than $3 \mu \mathrm{g}$. $/ \mathrm{ml}$., the $H_{50}$ value for a 45 min. incubation period. Thus, during the 4 contacts, more than $80 \%$ of the toxin had been removed from the solution.

A similar effect can also be demonstrated for staphylococcal $\beta$-haemolysin, although the latter has no lytic action against rabbit erythrocytes (Glenny \& Stevens, 1935). A solution containing $0 \cdot 17$ i.u./ml. of $\beta$-haemolysin was brought into contact with 4 batches of rabbit red cells, each treatment lasting 15 min. After removal of the fourth batch, the activity of the supernatant was tested against sheep erythrocytes, revealing a drop to about one-third of the original concentration (Table 1a).

\section{Table 1. Absorption of $\beta$-haemolysin by 'refractory' cells}

(a) A solution of $\beta$-haemolysin, containing $0 \cdot 17$ i.u. $/ \mathrm{ml}$., was incubated 4 times with a $1 \%$ suspension of rabbit erythrocytes. Each treatment lasted for 15 min.; temperature $37^{\circ}$. After the fourth batch of cells had been removed by centrifugation, the activity of the supernatant was tested against sheep erythrocytes by the hot-cold method. Part of the $\beta$-haemolysin solution, which was not in contact with rabbit cells, but otherwise was exposed to the same experimental conditions, served as control.

Control

Solution incubated with 4 batches of rabbit red cells

$\begin{array}{cc}\begin{array}{c}\text { Dilution of } \\ \text { supernatant }\end{array} & \begin{array}{c}\% \\ \text { Haemolysis }\end{array} \\ 1 / 34 & 50 \\ 1 / 14 & 14 \\ 1 / 10 & 48 \\ 1 / 7 & 85\end{array}$

(b) A solution of $\beta$-haemolysin, containing $0.025 \mathrm{i} . \mathrm{u} . / \mathrm{ml}$., was incubated at $37^{\circ}$ with 3 batches of $1.5 \times 10^{7}$ Ehrlich ascites tumour cells for $15 \mathrm{~min}$., the cells being removed each time by centrifugation. The final supernatant was tested against sheep erythrocytes.

Control

Dilution of supernatant

$\%$

$1 / 5$

Haemolysis

After treatment with 3 batches of tumour cells

It has been shown that staphylococcal $\alpha$-haemolysin affects not only erythrocytes, but alters also the permeability of rabbit kidney cells (Artenstein, Madoff \& Weinstein, 1963) and of Ehrlich ascites tumour cells (Madoff, Artenstein \& Weinstein, 1963). We have therefore examined the absorption of $\beta$-haemolysin by the latter. Incubation of $\beta$-toxin with 3 batches of ascites carcinoma cells, each time for $15 \mathrm{~min}$., reduced the lytic activity against sheep erythrocytes to about one-fifth (Table $\mathbf{1} b$ ). Direct inspection of the stained tumour cells failed to reveal any visible morphological change.

\section{Prelytic effect of $\beta$-haemolysin}

The experiments described above show that $\beta$-haemolysin was effectively bound to cells which do not form 'substrates'. This type of absorption may represent a purely physical phenomenon, or the $\beta$-toxin may induce a 'prelytic' change in the membrane structure, which in itself is insufficient to cause disruption of the cells. If such a change does take place, it should reveal itself by enhancement of the effect of other haemolytic agents.

Osmotic haemolysis. When rabbit erythrocytes, suspended in saline of $\mathrm{pH} 7$, are exposed to distilled water in the fragiligraph cell, haemolysis proceeds as shown 
by curve $a$ in Fig. 2. This process was characterized by two features: the lag period and the slope of the linear portion of the ascending branch. In the present experiments, we have selected the first parameter for the purpose of comparison.

Pre-incubation of rabbit red cells with $\beta$-haemolysin reduced the lag phase of osmotic lysis considerably. In Fig. 1 this effect is plotted as function of contact time. The lag period shortened progressively when exposure to a given concentration of $\beta$-toxin was prolonged. After 20 min. the value of the latency remained constant, indicating that the interaction of $\beta$-haemolysin with rabbit erythrocytes, a slowly progressing reaction, had been completed.

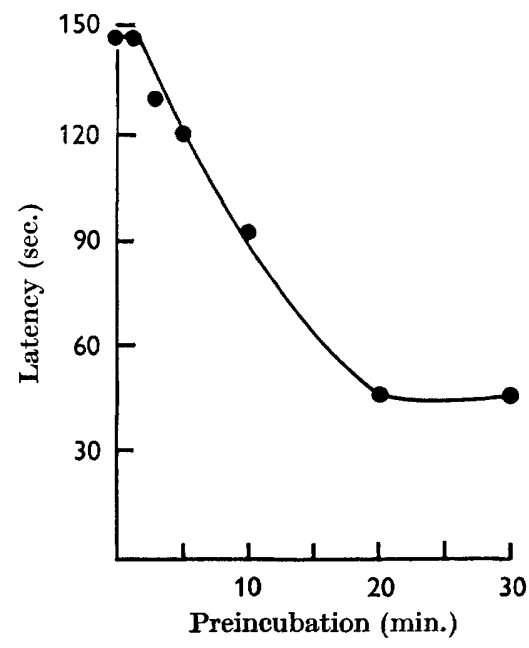

Fig. 1. Acceleration of osmotic haemolysis of rabbit erythrocytes by preincubation with $\beta$-haemolysin. A $1 \%$ suspension of rabbit red cells was incubated at $37^{\circ}$ with 0.05 i.u. $/ \mathrm{ml}$. of $\beta$-haemolysin, in the presence of PBS. Samples of this mixture were transferred at different times to the inner compartment of the fragiligraph and the progress of osmotic lysis was recorded. The latencies (ordinate), obtained from the fragiligraph curves, were then plotted as function of time of preincubation with $\beta$-haemolysin (abscissa).

Chemical haemolysis. Pretreatment of rabbit cells with $\beta$-haemolysin enhances the lytic action of other effective agents. This can be shown, for example, by exposing the erythrocytes first to the $\beta$-toxin for $20 \mathrm{~min}$. and subsequently treating them with prymnesin. Table 2 clearly manifests the synergistic effect of $\beta$-toxin by considerable acceleration of the lytic process of prymnesin.

\section{Is the prelytic effect of $\beta$-haemolysin reversible?}

If the membrane alteration, induced in rabbit red cells by $\beta$-haemolysin, is not too profound, the process may be reversible. Rabbit erythrocytes were therefore incubated with $\beta$-haemolysin at $37^{\circ}$ for $20 \mathrm{~min}$. After separation from the lytic agent, the cells were washed 10 times, at intervals of 5 min., with PBS and after $1 \mathrm{hr}$ the rate of osmotic lysis was measured. The result was the same as when the cells were transferred to the fragiligraph without washing. For instance, when the cells were incubated with 0.05 i.u./ml. for $20 \mathrm{~min}$., the lag period in the fragiligram was reduced from 3 to $1.5 \mathrm{~min}$. One hour later, when the cells had been washed 10 times, the lag period was still $1.6 \mathrm{~min}$. 

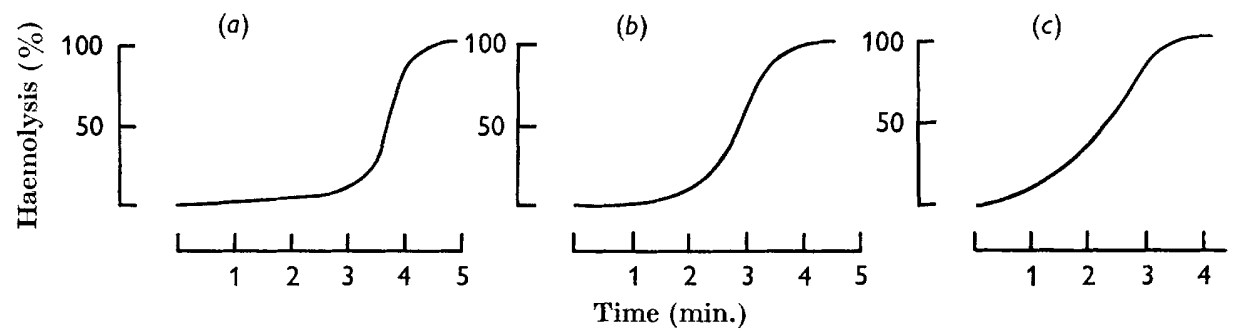

Fig. 2. Shortening of the latency of osmotic haemolysis of rabbit erythrocytes by brief incubation with prymnesin. $a$, Control; $b$, red cells left in contact with $3 \mu \mathrm{g} . / \mathrm{ml}$. of prymnesin for 30 sec.; $c$, preincubation with $3 \mu \mathrm{g} . / \mathrm{ml}$. of prymnesin for $3 \mathrm{~min}$. The cells were transferred to the fragiligraph without further treatment.

\section{Prelytic activity of prymnesin}

The observations with $\beta$-haemolysin suggest that enhancement of osmotic haemolysis may serve as a general method to detect small concentrations of lytic agents or to shorten the necessary observation time. As an example we show in Fig. 2 the effect of brief incubation (for $30 \mathrm{sec}$. and $3 \mathrm{~min}$. respectively) of rabbit erythrocytes with a concentration of prymnesin that causes $50 \%$ haemolysis within 45 min. During the short contact of the red cells with this material there was no visible lytic action, but subsequent measurement in the fragiligraph revealed a marked acceleration of osmotic haemolysis.

\section{Table 2. Synergistic effect of pretreatment of rabbit erythrocytes with $\beta$-haemolysin on prymnesin-induced haemolysis}

A $1 \%$ suspension of rabbit erythrocytes was incubated at $37^{\circ}$ with 0.005 i.u. $/ \mathrm{ml}$. of $\beta$-haemolysin for $20 \mathrm{~min}$. The cells were centrifuged off and subsequently incubated with $1 \cdot 1 \mu \mathrm{g} . / \mathrm{ml}$. of prymnesin at $37^{\circ}$. Red cells which had not been in contact with $\beta$-haemolysin served as controls. The progress of lysis was measured by the extinction of the supernatant at $540 \mathrm{~m} \mu$.

\begin{tabular}{ccc} 
& \multicolumn{2}{c}{$\begin{array}{c}\text { Cells after } \\
\text { pre-incubation with } \\
\beta \text {-haemolysin }\end{array}$} \\
Time (min.) & Control & 9 \\
5 & 3 & 20 \\
10 & 3 & 32 \\
15 & 5 & 53 \\
20 & 6 & 79 \\
30 & 13 & 89 \\
45 & 26 & 95 \\
60 & 46 & 100 \\
75 & 68 & - \\
100 & 83 & - \\
150 & 97 &
\end{tabular}

\section{DISCUSSION}

Marks \& Vaughan (1950), when studying the combined action of different staphylococcal haemolysins, observed additive as well as synergistic effects. The present experiments demonstrate that $\beta$-haemolysin, which is 'inert' towards rabbit erythrocytes, is nevertheless absorbed by these cells and induces a change 
of membrane structure, which can be recognized by combination with another haemolytic process. The combination method does not only detect covert effects, but can reveal prelytic actions in general and thus may measure concentrations of haemolytic agents too small to produce by themselves rupture of the cell membrane, or it may shorten considerably the incubation time required.

Davson \& Ponder (1938) have pointed out that two mechanisms are operative in haemolysis: $(a)$ stretching and rupture of the lipid membrane, and $(b)$ stretching of the protein mesh. The first effect is held responsible for the increased permeability of the red cell for cations, a phenomenon often encountered in the prelytic stage, while the second process may account for increased permeability for haemoglobin. The order $(a) \rightarrow(b)$ is assumed to hold for osmotic lysis. Since $\beta$-haemolysin has only a prelytic effect on rabbit red cells, the question arises whether its incomplete action can be related to one of the two steps required to accomplish full haemolysis.

Doery, Magnusson, Gulasekharam \& Pearson (1965) showed that $\beta$-haemolysin exerts two enzymic activities, namely of sphingomyelinase and of lysophospholipase. Furthermore, Doery, Magnusson, Cheyne \& Gulasekharam (1963) found that the sphingomyelin in the stroma of lysed rabbit erythrocytes is hydrolyzed by $\beta$-haemolysin qualitatively in the same way as sheep sphingomyelin. However, in spite of the susceptibility of the stroma-bound sphingomyelin in rabbit erythrocytes to enzymic attack, the treated cells do not release haemoglobin even when exposed to cold.

Similar phenomena have been described by MacFarlane (1950) for the toxins of various clostridium species. Thus the 'hot-cold' $\alpha$-toxin of Clostridium welchii is much more effective against sheep than against rabbit erythrocytes. Haemolysis of rabbit red cells is not only weaker, but also is not altered by subsequent cooling. All clostridial toxins exhibit lecithinase activity and the enzymic rates can be compared by using egg lecithin as standard substrate. MacFarlane (1950) attempted to relate divergencies in haemolytic action to different rates of lipid hydrolysis. Indeed, sheep erythrocytes liberated acid-soluble phosphorus much faster when treated with $\alpha$-toxin of $C$. welchii than when exposed to the $\gamma$-toxin of $C$. oedematiens, to which they are much less sensitive. However, when the phospholipids were first extracted from the sheep cells with alcohol-ether and then subjected to the hydrolytic action of the lecithinases, the same rate of splitting was found with either $\alpha$ - or $\gamma$-toxin. Apparently, the phospholipids, when incorporated into a specific membrane structure, change their susceptibility to enzymic attack.

One may be tempted to explain the different sensitivity of rabbit and sheep erythrocytes to staphylococcal $\beta$-haemolysin on a similar basis. Thus, Doery et al. (1963) assumed that the sphingomyelin in whole sheep cells is more easily accessible to the enzymes than the corresponding substrate in rabbit erythrocytes. De Gier \& van Deenen (1961) found a marked difference in the lipid composition of the red cells of these two species. The sheep cells contain much less lecithin, but considerably more sphingomyelin and lysophosphatides than do rabbit erythrocytes. It is known that cells with a lower lecithin content undergo more rapid lysis in isotonic glycol (Jacobs, Glassman \& Parpart, 1950). In a similar fashion, Doery et al. (1965) suggested that enzymic breakdown of sphingomyelin and related lipid components may cause more profound damage to sheep than to rabbit erythrocytes. Still, the differences in rate or extent of splitting of phospholipids cannot explain the effect of 
subsequent cooling. As Oakley, Warrack \& Clarke (1947) pointed out, 'something is involved in the haemolysis of these different types of red cells, besides the enzymatic attack on lecithin'. The nature of the cold reaction, which takes place in sheep erythrocytes but is absent in rabbit cells, remains one of the most intriguing problems of haemolytic mechanisms.

It should be recalled here that $\beta$-haemolysin exerts also an antagonistic action against many smooth-muscle stimulants (Anderson, James \& Marks, 1954; Kelsey \& Hobbs, 1954; Bergmann, Leon, Chaimovitz \& Benzakein, 1961). This effect too may be ascribed to enzymic alteration of the lipid layers in the smooth-muscle membrane. However, the inhibitory action on the guinea-pig ileum can be reversed by repeated washings, in contrast to the irreversibility of the prelytic change in rabbit red cells.

The authors thank Dr A. Gunders and Professor D. Nelken for the use of their fragiligraph. They are also obliged to Mr Z. Paster of the Department of Zoology for the supply of prymnesin.

\section{REFERENCES}

Anderson, K., James, D. M. \& Marks, J. (1954). The action of staphylococcal toxins on isolated rabbit intestine. J. Hyg., Camb. 52, 492.

Artenstein, M. S., Madoff, M. A. \& Weinstein, L. (1963). Studies of the biologic activity of purified staphylococcal alpha-toxin: I. The effect of alpha-toxin on cells in tissue culture. Yale J. Biol. Med. 35, 373.

Bergmann, F., Parnas, I. \& Reich, K. (1964). The action of the toxin of Prymnesium parvum Carter on the guinea-pig ileum. Br. J. Pharmacol. 22, 47.

Bergmann, F., Leon, S., Chaimovitz, M. \& Benzakern, F. (1961). A comparative study of staphylococcus haemolysins and colisan. Br. J. Pharmacol. 17, 159.

Cooper, L. Z., Madoff, M. A. \& Weinstein, L. (1964). Hemolysis of rabbit erythrocytes by purified staphylococcal alpha-toxin. II. Effects of inhibitors on the hemolytic sequence. $J$. Bact. 87, 136.

DANon, D. (1963). A rapid micro method for recording red cell osmotic fragility by continuous decrease of salt concentration. J. clin. Path. 16, 377.

Davson, H. \& Danielit, J. F. (1938). Studies on the permeability of erythrocytes. V. Factors in cation permeability. Biochem. J. 32, 991.

Davson, H. \& Ponder, E. (1938). Studies on the permeability of erythrocytes. IV. The permeability of 'ghosts' to cations. Biochem. J. 32, 756.

De Gier, J. \& van Deenen, L. L. M. (1961). Some lipid characteristics of red cell membranes of various animal species. Biochim. biophys, Acta, 49, 286.

Doery, H. M., Magnusson, B. J., Cheyne, I. M. \& Gulasekharam, J. (1963). A phospholipase in staphylococcal toxin which hydrolyses sphingomyelin. Nature, Lond. 198, 1091.

Doery, H. M., Magnusson, B. J., Gulasekharam, J. \& Pearson, J. E. (1965). The properties of phospholipase enzymes in staphylococcal toxins. J. gen. Microbiol. 40, 283.

Glenny, A. T. \& Stevens, M. F. (1935). Staphylococcus toxins and antitoxins. J. Path. Bact. 40, 201.

Jackson, A. W. \& Litrue, R. M. (1957). Staphylococeal toxins. I. Factors affecting the hemolytic activity of alpha toxin. Can. J. Microbiol. 3, 47.

J ACKson, A. W. \& Mayman, D. (1958). Staphylococcal toxins. IV. Factors affecting hemolysis by $\beta$-lysin. Can. J. Microbiol. 4, 477 .

JАСOB, H. S. \& JANDL, J. H. (1962). Effects of sulfhydryl inhibition on red blood cells. I. Mechanism of hemolysis. J. clin. Invest. 41, 779. 
Jacobs, M. H., Glassman, H. N. \& Parpart, A. K. (1950). Haemolysis and zoological relationships. Comparative studies with 4 penetrating non-electrolytes. $J$. exp. Zool. $113,27 \%$.

Kelsey, J. C. \& Hoвbs, B. C. (1954). Studies on the effect of staphylococcal culture filtrates on isolated rabbit gut. J. Hyg., Camb. 52, 502.

Macfarlane, M. G. (1950). The biochemistry of bacterial toxins. 5. Variation in haemolytic activity of immunologically distinct lecithinases towards erythrocytes from different species. Biochem. J. 47, 270.

Madoff, M. A., Artenstein, M. S. \& Weinstein, L. (1963). Studies of the biologic activity of purified staphylococcal alpha-toxin. II. The effect of alpha-toxin on Ehrlich ascites carcinoma cells. Yale J. Biol. Med. 35, 382.

Madoff, M. A., Cooper, L. Z. \& Weinstein, L. (1964). Hemolysis of rabbit erythrocytes by purified staphylococcal alpha-toxin. III. Potassium release. J. Bact. 87, 145.

Marks, J. \& Vaughan, A. C. T. (1950). Staphylococcal haemolysin. J. Path. Bact. 62, 597. Menk, W. (1932). Zur Wirkung des Pararauschbrandhämolysins. Zentbl. Bakt. ParasitKde, Abt. I, Orig. 123, 55.

OAKley, C. L., Warrack, G. H. \& Clarke, P. H. (1947). The toxins of Clostridium oedematiens (C. novyi). J. gen. Microbiol. 1, 91.

Reich, K., Bergmann, F. \& Kidron, M. (1965). Studies on the homogeneity of prymnesin, the toxin isolated from Prymnesium parvum Carter. Toxicon, 3, 33. 